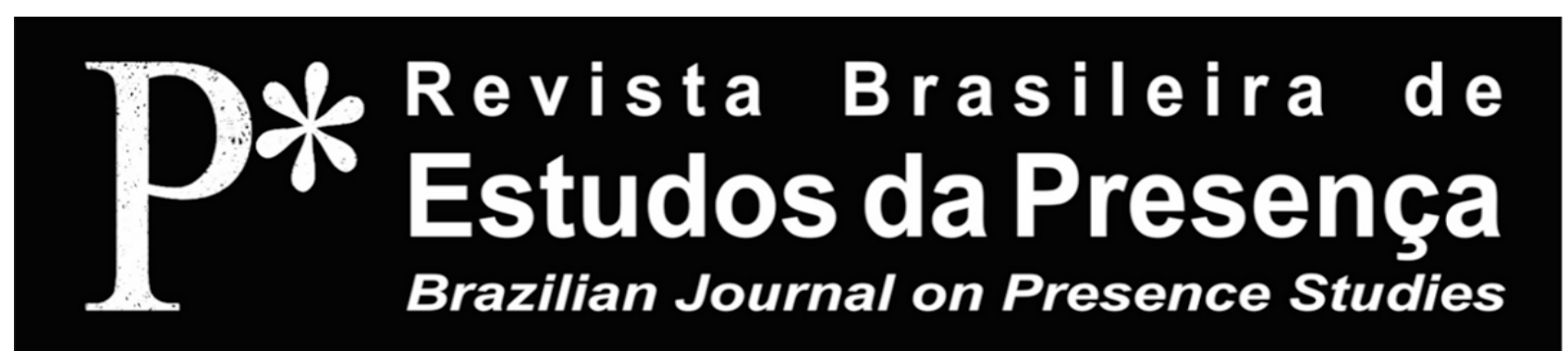

PERFORMANCE PHILOSOPHY

E-ISSN 2237-2660

\title{
Borders between Performing Arts and Philosophy
}

\begin{abstract}
Charles Feitosa'
'Universidade Federal do Estado do Rio de Janeiro - UNIRIO, Rio de Janeiro/RJ, Brazil
\end{abstract}

\begin{abstract}
Borders between Performing Arts and Philosophy ${ }^{1}$ - Apparently, philosophy has nothing to do with performing arts, as its environment is purely theoretical and eminently abstract, while the word performance refers to the notions of operation, implementation, action. I propose here the reoccupation of the borders between philosophy and performance arts by means of a reflection on the following points: 1. What is the performance of philosophy?; 2. What can philosophy say about performance?; 3. Which are the possible forms of composition between philosophy and performing arts?
\end{abstract}

Keywords: Body. Action. Performance. Thought. Interdisciplinarity.

RÉSUMÉ - Frontières entre les Arts de la Scène et la Philosophie - Apparemment la philosophie n'a rien à voir avec les arts de la scène, parce que son environnement est purement théorique et éminemment abstrait, tandis que le terme performance se rapporte aux notions d'opération, d'exécution, d'action. Je propose ici la réoccupation des frontières entre philosophie et arts de la performance par une réflexion sur les points suivants: 1. Quelle est la performance de la philosophie?; 2. Que peut dire la philosophie sur la performance?; 3. Quelles sont les formes possibles de composition entre la philosophie et les arts de la performance?

Mots-clés: Corps. Action. Performance. Pensée. Interdisciplinarité.

RESUMO - Fronteiras entre as Artes da Performance e a Filosofia - Aparentemente a filosofia nada tem a ver com as artes da performance, pois seu ambiente é meramente teórico e eminentemente abstrato, enquanto o termo performance remete às noçóes de operação, execução, ação. Propóe-se aqui a reocupação das fronteiras entre filosofia e as artes da performance através de uma reflexão sobre os seguintes pontos: 1. Qual é a performance da filosofia?; 2. O que a filosofia pode dizer sobre a performance?; 3. Quais são as formas possíveis de composição entre filosofia e as artes da performance?

Palavras-chave: Corpo. Ação. Performance. Pensamento. Interdisciplinaridade. 
The time is coming when it will hardly be possible to write a book of philosophy as it has been done for so long: 'Ah! the old style .. .'. The search for new means of philosophical expression was begun by Nietzsche and must be pursued today in relation to the renewal of certain other arts, such as the theatre or the cinema (Deleuze, 1968, p. 4).

\section{Performance of Philosophy}

\section{The Philosophical Acting}

Philosophy seems to have nothing to do with performance, as it is about a supposedly abstract and theoretical doing. However, there is a performative dimension of philosophy, a modus operandi in its thinking, a certain way of acting that distinguishes it from other existing theories of the world. Among the several characteristics that make up the performance of philosophy, I emphasize only three here as work hypotheses. First, philosophy can be seen, in a broad sense, as a deconstruction gesture ${ }^{2}$. It is a doing mediated by an undoing of the world, of the others and of ourselves. Deconstructing is not destroying, but rather disassembling. It is a type of reality making of. In general, we tend to look at things around us as if they were something that exists without our participation. The same happens when we say that we are stuck in a traffic jam. Such a banal and daily sentence addresses the traffic jam as a process beyond our will, as an obstacle that is in the middle of our way home, as if our car were the only one having the right to be in the streets. The traffic jam is always someone else's fault. In contrast, from the point of view of a philosophy disassembling look, it would be much more coherent to call our friends and tell them that we will be late for dinner because we are quite busy producing, with a crowd, a pretty huge traffic jam. The philosophical undoing unveils that reality is not something ready and given, but that it has been historically constructed each time in different ways, thus being possible to be reconstructed whenever necessary.

Second, philosophy is also ontology (from the Greek öv ón, entity, being, and $\lambda$ óyos, discourse, doctrine), that is, investigation for the meaning of the being ${ }^{3}$. In Plato's dialogues, such concern is clear by means of different emblematic situations that are reproduced until the present in any philosophy classroom. Socrates asks, for instance, what is the being of 
beauty. Instead of a general wording that accounts for all the situations, the interlocutor begins to give particular examples, like beauty is a beautiful woman, as Helen of Troy. All of Socrates' effort (and of any philosophy teacher since then) is to share the perception that the question aims at beauty in itself, that which makes both Cleopatra and Giselle Bündchen to be considered beautiful, regardless of their historical contexts. Philosophy is distinct from other gestures of knowledge precisely for this constant search for what is the most universal, even when it is increasingly clear that it is not possible to find a definite answer.

Finally, a third remarkable characteristic of the philosophical act, the one that interests us the most here, is its attitude of constant attention with language $e^{4}$. Such care with words and concepts can cause the impression of extreme formality to philosophy, as if it were only an infinite and unproductive terminological issue. Try to say I love you to a philosopher. Probably the reply will be: What is 'love'? or What is it for? In his book The Passions of the Soul (1649), Descartes claims in article 97 that the one who loves feels "[...] a gentle warmth in the chest; and food is digested very quickly in the stomach, so that love is beneficial to health" (Descartes, 1953 , p. 741). Actually, words are powerful for us, philosophers, and quite often they establish what we are and how we live in the world. The example that I frequently mention in lessons and lectures is a newspaper article from Rio de Janeiro in the 1980s, whose headline in huge block letters in the first page was: Minor Robs a Child. Please notice that it is not about a minor robbing a minor, nor a child robbing a child! The choice of words and concepts is never neutral or accidental, it unveils our political, ethical and aesthetic views. The terms and concepts used by us in daily, academic or professional discourses also use us, and sometimes take advantage of us.

\section{Borders $x$ Limits}

Within this context, I intend to perform a little of philosophy teasing the word borders, which entitles this paper. Nowadays, the expression without borders is trendy as a symbol of a humanitarian project (see the organizations of doctors, lawyers, scientists and even performers without borders). I have nothing against the beautiful work developed by these organizations, but as a philosopher I observe a mix-up in the use of the word. The French philosopher Regis Debray goes even farther when claiming that it is about 
"[...] a silly idea that charms the West: humankind, which is not doing well, will do better without borders" (Debray, 2010, p. 13). The expression without borders intends to mean, actually, without limits or without barriers. Although being often used as synonyms, there is a subtle, however crucial difference, between limits and borders that merits being recovered. The word limit, from the Latin limes, was created to circumscribe a place, a region or a territory. It is that line that gives identity or keeps cohesive a politicalterritorial unit. Limit expresses the end, the more or less clear point of exhaustion or depletion of a process or activity. Also, the limit, either spatial or secular, always concerns to the interior of a body, region or process. In turn, the border, in contrast with the limit, is a line that also refers to what is external. Actually, it is not even a homogeneous line, but much more an irregular zone of mutual communication and incorporation between the external and the internal world. The etymology of the word border takes back to the frontline, to the forehead, to the part that is further ahead of something. The French frontiere was first used as the "most advanced part of an army", and from there to "field of operations in contact with the enemy, areas of interaction between armies or lands". In political geography, the border "[...] is the contact zone between different worlds, between particular and logical social - but not necessarily opposing - formations" (Santos, 2011, p. 3).

Both terms indicate demarcation areas, but while the word limit refers to the contour to be defended, to the line where a territory ends, the word border always points also to what is on the other side of the territory, for its expansion. Why it is important then to surpass the limits, but to defend the remaining of the borders? Because the limits hinder the crossings, while the borders agency them. Now think about our skin. It is not about a barrier between us and the world, but rather an interaction zone, without which our life would not be possible. The skin is the border that we inhabit, we are all people of the border in relation to it ${ }^{5}$.

The border, in contrast with the limit, carries this strange ambiguity of restricting us, but also of constituting us; of distinguishing us, but also of opening us to the world. Defending the borders is not preventing the invasion of the foreigner, but to guarantee the conditions of possibility so that he/she, the foreigner, can reach the foreigness that is proper to him/her. The distinction between limit and border can function as a decisive criterion 
in the clash between the different ways of performing the philosophy in its history. In Kant's and Austin's analytical way, for instance, philosophy was described as the gesture of establishing limits and partitions, demarcating the lines of interdiction of the reason, the non-surmountable abysses between what we can, or not, to know, say or do. In turn, Hegel, in a dialectic way, warned that only those who are in some way beyond the limits are aware of them. It is proper of the dialectic reason to run over the limits or to expand towards the totality. More recently, in the Heideggerian/phenomenological way, it is considered that the whole is an unattainable illusion and that the philosophical act consists of unveiling that our limits are never set by some form of preordering of the space to which we would be entitled. Just like a parody of Antonio Machado's renown poem verse (Traveler, there's no road, the road is your travelling), it is as if Heidegger were whispering in our ears: There are no limits for the thinking before the experience of thinking itself. It is defended, thus, that the reinterpretation of the limits not as barriers anymore, but as borders (interchange zones), depends on the way we inhabit the world. Going even farther, in the contemporary way (Derridean/Deleuzian), it is understood that it is the bridges themselves that make it possible the existence of the banks of the river, not the opposite. Twenty-first century philosophies, as they assume themselves as post-metaphysical, have the priority to establish more and better bridges instead of further reinforcing the distance between the banks.

All the present teasing with the word border is, therefore, only a preparation for the following assertion: we claim a philosophy without limits, but not without borders. In this sense, the title of the present essay, concerning the borders between the fields of performing arts and philosophy, wants to point to the importance of creation and preservation of an interaction zone between them, to be occupied and expanded from this point on.

\section{Philosophy on Performance}

\section{The Birth of the notion of Performance in the Philosophies of the Language}

Defining performance is not easy. Relying to the etymology of the term, it can be observed that it takes back to the French verb parformer, which means doing, fulfilling, getting, concluding, taking some task to its 
success. One of the major scholars of the subject, Professor Richard Schechner, researcher in the field of Performance Studies of the New York University (NYU), lists the following situations in which performance can happen: daily life, arts, sports, business, technology, sex, sacred and secular rituals, games etc. Also, he lists the respective functions that it can exert in each case: to entertain, to say something beautiful, to mark the identity, to encourage a community, to heal, to teach, to persuade, to deal with the sacred etc. The performance notion is so vast that Schechner concludes that "[...] any event, action or behavior can be examined as if it were performance" (Schechner, 2003, p. 48) and analyzed in terms of action, behavior, exhibition.

The word performance is omnipresent nowadays, either in the propaganda, the arts, the economy or the politics. However, curiously, it was precisely a philosopher who introduced the word in the academic and cultural world. In 1955, the English philosopher John Langshaw Austin offered his renown William James Lectures in the University of Harvard. These conferences, published posthumously in 1962 under the title How to do things with words?, have marked the history of the contemporary philosophy for drawing attention to an aspect of the language that was neglected until then, the performative: "When I say, in front of the judge or in the altar, etc... 'I do', I am not reporting a wedding, I am getting married. How would you call a sentence or issuance of this type? I propose to call it performative sentence or performative issuance, or, in a shortened form, 'a performative'" (Austin, 1975, p. 6).

In confrontation with the traditional obsession for the distinction between true $\mathrm{x}$ false in the philosophy until then, Austin proposes a discussion on the enunciates that are neither true nor false, they neither describe nor serve to inform, anyway, they are not referential, but rather they do something. Despite the important contribution, it is obvious the indication that, for Austin, the discovery of the performative dimension of the language serves only to its better neutralization. The British philosopher does not hide that he prioritizes communication as a primary function of the language, and he calls the poet's or actor's discourses as "parasitic uses of the language, that 'are not taken seriously', or do not 'constitute its full normal use'” (1975, p. 22). Austin's declared intent is to purify the constative claims (typical of philosophy and science) of any trace of 
performative contamination, even though he admits not being possible yet to elaborate perfect criteria of separation.

It is precisely in this attempt to establish a clear and distinct division between the constative and the performative that Austin's theory wobbles. What is there is much more borders than limits, that is, heterogeneous and irregular zones of structural and reciprocal contamination. Let's resume the example previously given, of trying to say I love you to a philosopher. How to establish a clear distinction here is about an constative, an operation or a gesture aimed to some production of effect? The contexts of each claim function as shufflers of too stiff distinctions. There is always something of constative in the supposedly performative sentences, just like there is always something of performative in the claims that it is believed to be merely constative. There is no purity, except in the catalogues of the philosophers at service of the limits and against the borders ${ }^{6}$.

\section{The Performative Turn in the Studies of Society and Culture}

Some see in Austin's inquiries the positive aspect of allowing the possibility for the historical rehabilitation of the sophists' works, who for a long time understood that the discourse is capable of operating, transforming and creating worlds ${ }^{7}$. Actually, for the contemporary philosophy, which considers the language as the constituting structure of reality itself, the question is not anymore how to do things with the words?, but rather how would it be possible to do anything without words? In the contemporary ontologies, the performative dimension is not a parasitic function of the language only, but rather its major form of manifestation.

If the word performance emerged in the philosophy of the language, already in the 1980s and the 1990s it started to occupy a central place in the feminism, especially in the issues regarding the deconstruction of the ideology that considers gender as an inexorable determination of nature. The North American philosopher Judith Butler, author of several books on the topic, defended the thesis, already in 1988, that the sexual identity is not biological, but rather the result of an institutionalization by means of stylized repetition of ritualized acts and gestures. Gender is not something that one is, but something that one does: 
In this sense, gender is in no way a steady identity or the locus of agency from which several acts derive; instead, it is an identity arduously constituted in time - an identity instituted by means of a stylized repetition of acts. Moreover, gender is instituted by means of the stylization of the body and, therefore, it must be understood as the mundane way by which the corporal gestures, movements and staging of several types constitute the illusion of a permanent gender being (Butler, 1988, p. 519).

What we assume as gender identity is, then, a sequence of gestures. However, it is not as if there were an actor behind the acts performed, as it is when performing the act that, performatively, the subject is constituted. What happens is that, once gender is assumed as an eternal and unchanging substance, it becomes seen as if it were something natural. The gender performativity, in turn, points not only to what a person does, but also to what the society does with her/him. The great merit of Butler is to dislocate the gender discussion from biology to cultural studies, especially when questioning the hegemony of the heteronormative identities that are imposed by the media, pedagogy and science.

The tension between performativity $\mathrm{x}$ essentialism that dominated the gender studies happened in a more or less parallel way to the so-called performative turn of the social sciences from the second half of the $20^{\text {th }}$ century on. The performative turn in sociology and anthropology emerged with the increasing awareness of the intrinsic connection between daily, sacred and ludic rituals that constitute the human society. Rather than assuming a previous essence of the cultures that would be expressed by means of practices and processes, the new approach starts to consider these cultural practices as situations in which the cultural and social frameworks are created, sustained and transformed. In the social sciences, the major representatives of this turn are the British sociologist Victor Turner (19201983), a great scholar of the rites of passage, and the aforementioned Professor of the NYU Richard Schechner (1934-).

Turner aimed to describe the various facets of the ritualizing processes that constitute human life in society, from daily life, sports, religion, politics, to the theater: "If the human being is a sapient animal, who manufactures instruments, that creates himself, that uses symbols, then he is also an animal that performs, Homo Performans" (Turner, 1988, p. 81). Performance here means "the presentation of him/herself in the daily life". 
Turner developed the concept of "social drama", which bets in an analogy between social processes and theatrical/dramatic structures: ruptures in the social relationships generate crises that will demand either agonistic views or reintegration procedures: "The social drama, then, I see as the experimental matrix from which the various genres of cultural performance are generated, starting by compensating rituals and legal procedures and eventually including oral and literary narratives" (Turner, 1992, p. 78).

While Turner was a sociologist who appealed to the theater to better understand the social structures, Richard Schechner is a scholar of the performing arts who searched in anthropology for the necessary instrumental for a better understanding of the contemporary forms of theater. In 1977 he published the book Between Theather \& Anthropology, in which published it is defended the thesis that between art and life there is no clear and distinct demarcation, but rather a fluid cross-border zone that should be investigated:

The convergence between anthropology and theater is part of a wider intellectual movement in which the understanding of human behavior displaces the focus from the quantifiable differences between cause and effect, past and present, form and content, etc. (and the linear ways of analysis that explain such way of seeing the world) to an emphasis on the deconstruction/reconstruction of reality (Schechner, 1985, p. 33).

It is from these points of contact between anthropology and theater that Schechner develops his major concept, restored behavior: in every social ritual, just like in theater, there are organized sequences of events, prescribed actions, typical gestures, that are not mixed-up with those who practice them. These performances can be filed, broadcasted, manipulated and transformed, recombined, similar to how a filmmaker edits a film. The processes in which these mediations happen, by means of countless repetitions and differentiations, are the link connecting artistic and cultural performances: "in the day-by-day, in the shamanic healings, in the tricks and in the arts" (Schechner, 2011, p. 33).

In 1980 Schechner managed that the department of preforming studies in the NYU became called department of performing studies, and from then on, the new discipline began to be disseminated and expanded to several universities of the world. In Brazil, one of the pioneers in the research work in cultural performing is Professor Zeca Ligiero 
(Universidade Federal do Estado do Rio de Janeiro - UNIRIO), who held his $\mathrm{PhD}$ in performing studies from the NYU. Zeca Ligiero established in 1998 the Center of Studies of Afro-Amerindian Performances (NEPPA) and has been since then dedicated to the occupation and expansion of the borders between anthropology and performing arts, in the path inaugurated by Turner and Schechner. But it is in the field of arts that the notion of performance acquired the biggest visibility.

\section{Rise of the Performing Arts}

In September 2017 the decontextualized dissemination of videos showing a child interacting with a naked artist, the choreographer Wagner Schwartz, in the performance La Bête, in the Modern Art Museum of Sáo Paulo, generated a wave of violent accusations of child pornography on the part of the most conservative sectors of the society. Although the Federal Attorney's Office shut down the investigations, denying any violation of children's rights, the debates on the limits of the autonomy of the artwork and on the aesthetic value of performing arts were revived.

The performances that caused such a big controversy in Brazil in 2017 did not come out of nowhere, but they date back to the happenings, live art and conceptual art movements from the 1960s and the 1970s. These, in turn, were inspired by the pioneering experimentations of the artists from the beginning of the $20^{\text {th }}$ century, like the surrealists and the Dadaists. In Brazil, one of the pioneers is Flavio Carvalho, also known as a performer before the performance, as he developed, already in the 1950s, his controversial social psychology experiences, like the very famous Experiência $n^{o} 2$ (1956), which consisted of walking against a Corpus Christi procession in downtown São Paulo, wearing a hat.

The performing arts do not have limits, but rather borders, zones of interaction with painting, sculpture, theater, music, cinema, technology etc. It is a form of scenic expression, but that differs from the traditional theater for not wanting to represent or reference nothing outside itself. This nonnarrative, non-discursive, non-mimetic character makes the performing arts to be seen as hybrid and unpredictable, but they have in common: (1) more emphasis on the action than on the workmanship, (2) on the ephemeral character of the process, (3) on the experimentation and improvisation, (4) 
on the centrality given to the body and (5) to the materiality in general. According to Renato Cohen, founder of the group Lume and pioneer in the studies of performing arts in Brazil: "[...] a picture being exhibited to an audience does not characterize a performance; somebody painting this picture, live, could characterize it" (Cohen, 2002, p. 28).

Unlike the traditional theater, the performing arts prioritize the contingency in detriment of a preexisting script; they shuffle the traditional division between actors and audience, actors and their respective roles and mainly, between art and life. The autobiographical dimension and the daily life are the basic material for the performing arts. In the turn of the $20^{\text {th }}$ to the $21^{\text {st }}$ century, the performing arts acquired great visibility, being Marina Abramovic, born in Belgrade in 1946, the most renown name by the public. In one of her most famous performances, intitled Ritmo 0, of 1975, the artist placed 72 item on a table - among them, an axe, a pistol and a bullet - and stayed for six hours in Galleria Studio Morra, Naples, to the disposal of the public, so that they could make whatever they wanted with her, without resistance. In 2012, she launched the documentary on her own itinerary with the emblematic heading of A Artista está Presente [The Artist is Present]. The presence of the artist seems to establish the distinctive element of the performing arts, that is, the instauration of an immediate and absolute here and now between the performer and her/his audience. We will see in the following item that while the production of presence is one of the tonics of the performing arts, it also constitutes its most problematic aspect, at least from the philosophy point of view.

The important here is to point out that the artist's body, vulnerable to the chances and intensities coming from the most diverse desires, became the artwork itself. The rise of the performing arts has contributed, among other things, for a revitalization of theater itself in the contemporary age. Despite the differences, both the German critic and theater Professor HansThies Lehman and the critic and Canadian Professor Josette Féral, with their respective concepts of post-dramatic theater and performative theater, try to give account of the advent of forms of dramaturgical expression that are inspired in the performing arts to weaken the text-centrism, the subordinate role of the spectator, the emphasis on the representation and the narrativity of the so-called classic theater ${ }^{8}$. The great visibility of the performing arts in the contemporary scene has also caused, on the other 
hand, several negative reactions, that came not only as accusations of obscenities, as in the aforementioned case of La bête, but also for not respecting the sacrosanct limits between what must or not be the topic of artistic expression. But who, among rulers, critics, policemen, magistrates, scientists, public in general, has the right to decide what is art or not?

A more scathing criticism, however not less questionable, came from the Colombian journalist Ursula Uchoa, who, in a blog in 2008, accused the performing arts of having become a pastiche of themselves, by means of the exacerbated repetition of some gestures, which may have had their contesting power at some moment, but that became clichés only. The post that reached over 150 thousand views makes a visual compilation with photographs of different performances, thus composing the 10 most used gestures in the performance: I. Nudity; II. Wearing red; III. Using raw meat; IV. Using blood as ink; V. Vaginal painting; VI. Smearing the body with foods or fluids; VII. Wrapping the head with laces, elastic bands etc.; VIII. Writing in the body; IX. Using ice; X. Action painting (Uchoa, 2008, online). For each one of these gestures, Uchoa assembled a mosaic of photos from different works, without naming, dating or contextualizing them.

Everything happens as if the performing arts had become something against which they had always fought: a catalogue/vocabulary with rules and prescriptions for the good aesthetic functioning of an action. According to Uchoa, the "gesture-cliché" (despite the fact that she does not use this expression specifically) impoverishes the performing arts: "These gestures, costumes, subjects and forms of developing the art of the action are increasingly becoming an easy way to justify our unhealthy and vividly unjustifiable creative mediocrity" (Uchoa, 2008, online). The article was strongly criticized by researchers and performers from the whole world. In Brazil, the performer and Professor Bia Medeiros, coordinator of the research group Corpos Performáticos, wrote an essay replying to Uchoa's kind of fast accusations, emphasizing that: "The performance is not language, it has no grammar nor vocabulary, there is no alphabetical order or rules" (Medeiros, 2010, online).

Actually, the text of the Colombian journalist can even be heard as a warning for the risk that contesting and innovations in art and politics can be recaptured by the system and start to serve as its own propaganda. This is what happened with the hippie and punk movements in the 1960s and 
1970s. But Uchoas's accusations are not only generalizing, the way how she supports them also implies in a certain argumentative trap. When collecting photos from different shows, different times and places, and placing them side by side, as if they were comparable, she runs over the differences and nuances of each one of the works represented there. It may be that some of them have even been lost in an empty repetition, but certainly others caused an intense displacements of our perspectives of the real. What Uchoa makes is to abstract (to separate and to fixate) one only aspect of a much more complex process and to freeze it under a simplifying aegis. With this, it is stolen from us the chance to evaluate on our own the strength or the weakness of each one of the works exhibited. Ultimately, Uchoa advocated the use of the same strategy of the moralist detractors of the performance $\mathrm{La}$ Bête in Brazil, who were based on an excerpt of a video totally out of context to justify their accusations of pedophilia and indecent exposure.

\section{Philosophy Against and With Performing Arts}

\section{Presence $x$ Happening}

The contemporary philosophy also has criticisms to the performing arts, but they do not pass by no moral, political or aesthetic conviction, but rather within the already mentioned typical performative strategy of philosophy itself of teasing with the indiscriminate use of certain concepts. In the case of performance, the problem is its claim of being capable of producing presence, exempt and purified of any mediation. We have seen in the previous section that one of the most distinctive aspects of performing arts is the rupture with representation in the classic theater. In the traditional theater, in general, there is a tacit agreement with fiction, with the establishment of an illusory space and time, where actors and objects on stage are always leading to other people and other things, the scene always wants to make reference to another place, different, extraneous, from the outside. However, in the performance, as Cohen emphasizes, "[...] there is a much bigger accenting of the present instant, the moment of the action, what happens in the 'real' time" (Cohen, 2002, p. 97). The performing arts claim to themselves the affirmation of a pure presence, both of the performer in relation with her/himself and in relation with her/his audience, as the performer is not an actor there, she/he displays her/his own 
persona. This confers to the performative process the characteristic of a rite, with the audience not being only the spectator anymore, but rather in a type of communion. The relation between the spectator and the artistic object is displaced then from a mainly aesthetic relation to an ecstatic relation, similar to the deep meditation or the effect of hallucinogenic drugs, in which there is less psychological distancing between the object and the spectator. Everything happens as if the performing arts could offer a rare chance to escape from the ordinary of the daily life, in which we are imprisoned, either to the future or to the past.

Presence is, therefore, an essential aesthetic element for the performing arts. In 2016 I had a chance to participate in a round table on the Question of Presence in Philosophy and Performing Arts ${ }^{9}$ with my friend and colleague Renato Ferracini, director of the group Lume. In this debate, I argued that the human being lives historically, thus, he can even come closer, but will never reach absolute here and now. I also raised the controversial hypothesis that the apology of the presence in the performing arts is a residue of a metaphysical desire for eternity, typical of all the forms of mysticism, that worship a veiled resentment against the transience of time, accusing it unduly as being the cause of all our sufferings.

In the debate with Ferracini I claimed that, if presence is not accessible to the human beings, it does not mean that nothing singular happens with the bodies in scene, but it is something that demands another concept, much more appropriate to me. I have proposed the notion of happening, basic to the whole philosophy of the $20^{\text {th }}$ century, to give account of what, for me, is erroneously described by the artists and theoreticians of the performance as presence. But what is the difference between presence and happening, and why is it so important from the point of view of philosophy, to draw attention to this difference?

The notion of pure presence as it is described by its dedicated enthusiasts is directly linked to the metaphysical model of world, which is split in the oppositional and hierarchic structure between subject and object. Presence is what is right in front of me, at my complete disposal. The direct presence of any objects always assumes the immediate presence of the subjects for themselves, as full self-awareness. It is not that the performance in itself is metaphysical, but the way how it has been described, the terminology used to conceive it is still tied to dualist models. 
There is a mismatch between what is done and what is said. For the contemporary philosophy, however, there is nothing out or beyond mediatization. In this sense, the notion of happening seems like a form of intensification of time, but not of its suspension or stoppage.

The concept of time underlying the idea of happening is not the one of chrónos (linear, sequential, quantitative time), nor of aion (eternity, the out of time), but of kairós (the propitious occasion). By occasion it must not be understand the notion of a second, but rather any duration that implies in a breaking in the chronological linear process. Kairós is not a specific point of chrónos, much less its interruption. Kairós is qualified chrónos, is the propitious time for the actions and for the operations, it is the time of the performance ${ }^{10}$. When we leave home to go to work, all the stages of this process are at the service of the time of the chronometer, with starting, middle and arrival points. If, by any chance, a little suddenly, we are attracted and distracted by some incident, either a street music band, or some exceptionally interesting conversation, or by a mere desire to know what is at the end of the street, then we will detour from the goal, from the project of future, we start to live in the kairologic time, which can last for a few seconds, hours or even months or years. We do not leave time, we only live it in another way, with modified intensity, modulated by our different answers to the calls that perhaps the chance offers to us.

The time of the happening, therefore, is not out of time, nor the stoppage of time, it is not the pure now, but rather a modulation of temporality. The notion of happening dates back to Heidegger [in German: Ereignis] but was resumed by most philosophers from the $20^{\text {th }}$ and the $21^{\text {st }}$ centuries (Derrida, Agamben, Deleuze, Merleau-Ponty, Foucault, Badieu, Ranciére, and Sloterdijk, among others). It is Derrida who, in my opinion, better translates the idea of happening when understanding it as a singular situation, in which the other arrives, in her/his irreducible otherness. By definition, a happening belongs to the order of the imponderable, not being able to be foreseen nor calculated, much less anticipated. The determinant secular instance of the happening is not the present, but rather the future, however in a differentiated way. In the 2002 documentary on his work, Derrida: The Movie, he makes the following and important distinction between future and l'avenir [to come]: 
In general, I try to distinguish between what one calls the future and 'l'avenir'. The future is that which - tomorrow, later, next century - will be. There's a future that is predictable, programmed, scheduled, foreseeable. But there is a future, l'avenir (to come), which refers to someone who comes whose arrival is totally unexpected. For me, that is the real future. That which is totally unpredictable. The Other who comes without my being able to anticipate their arrival. So if there is a real future beyond the other known future, it's l'avenir in that it's the coming of the Other when I am completely unable to foresee their arrival (Derrida apud Derrida: The Movie, 2002, n. p.).

The performing arts offer to us an opportunity of the coming of an unexpected otherness and thus to experience time in a different way than in the linear modality. My thesis is that the performing arts produce happening, not presence. But the establishment of the kairós does not depend on our pure and mere decision, is a situation that transcends our will, as wanting things and planning to get them is an ability typical of the chronological time. Perhaps the time of the happening has more to do with our greater or lesser ability to keep ourselves passive and allowing things to come to meet us, without us judging, classifying or controlling them. This passiveness needs to be trained actively, because our main trend is to keep the focus on the plannable future. I believe that it makes all the difference to train the body of the performer to produce more and better happenings instead of presence effects. All this teasing with the centrality assigned to the notion of presence is not mere terminological details, but rather a form of engagement of the philosophy in the occupation of the border with the performing arts. This way, facing the task of thinking another ontology of the body in scene, either in the theater, or in dance or in the performance, beyond the dualists, essentialists and hierarchic models inherited from metaphysics. The training techniques, the creative processes and the poetical/political experimentations in the performing arts tend to be enriched with the debate with philosophy. And what can the philosophy learn with the performing arts?

\section{The Performative Turn of Philosophy in the $21^{\text {tt }}$ Century}

It is not enough to speak about, philosophy can and should allow itself to be contaminated by non-philosophers, especially artists of the performance. Perhaps it is possible to state that we are living a type of 
performative turn in the philosophy of the $21^{\text {st }}$ century. Not that the history of philosophy is completely devoid of gestures that could today be called performative actions. On the contrary, there are many famous emblematic situations in which the philosopher engaged his own body to intensify his ideas. Aristotle, for instance, accounted that the skeptical Cratylus, for believing that one does not have to say anything, only moved the finger. We can imagine Cratylus's pointed finger as a gesture of someone that silences out of conviction, but also of someone who demands that everybody around silence, summoning to think more and to say less. Socrates, shortly before drinking hemlock, made a performative ritual when asking for a rooster to be sacrificed to Asclepius, god of medicine and healing. Many saw in this unusual gesture of the thinker an early sign of the effluvium of the poison in his mind, but Nietzsche, in The Birth of Tragedy (1872), in contrast, recognized the Socratic tribute to the son of Apollo, "the only sign of respect to the limits of the logical nature" (Nietzsche, 1988a, p. 96) in all of Socrates life.

Jules Bonnet famous photograph showing Nietzsche and Paul Rée pulling a carriage with Lou Salome in the reins and the whip was a brilliant performative action staged by the German philosopher in May 1882, a scene that until today feeds several controversies. By the way, Nietzsche can be considered the catalyzer of the performative turn of the philosophy, as he always defended and assumed the autobiographic dimension in his own writing, made experiences with new medias, having been one of the first users of the typewriter on Earth and developed several partnerships both with artists (actors, musicians, poets, photographers etc.) and scientists (biologists, physicians, geographers etc.). He called for the coming of new philosophers in the future who would be distinguished by their capacity to recognize, like a fragment from the summer of 1885 , that "the body is a thought much more admirable than the old 'soul'" (Nietzsche, 1988b, p. 565). He brought the philosophy both to the stage and to the streets and created the concept of philosopher-artist, somebody who sees both philosophy and science as creative, therefore, political gestures.

More recently, it is the Spanish philosopher Paul Beatriz Preciado who will resume in a more radical way the thesis of the performing arts that the body is not something given and granted, but rather a fertile field for the accomplishment of possibilities. In the book Testo Yonqui (2008), he makes 
an investigation on gender, drugs and biopolitics in the pharmacopornographic age. Preciado accounts the experience of selfadministering testosterone, showing, demonstrating and at the same time reflecting on the technologies for body changes. It was a gesture simultaneously performative, philosophical and political, or, as Preciado says in the introduction: "[...] a protocol of voluntary poisoning based on synthetic testosterone"; a "corporal essay", a "self-political fiction" (Preciado, 2008, p. 15).

In 2012, it emerged in Europe an international initiative for the establishment of a new field of knowledge called performance philosophy, that brings together in an organized and consistent way the creative practices of performances and the conceptual work of philosophy. In a round table on the topic What is philo-performance? in 2014, the Professor and researcher of the University of Paris VIII, Charlotte Hess, answered to the question in the following way:

By philo-performance we understand the staging of the thought in all its forms: spoken and dueled philosophy, slam, social intervention, dance, research action, festivals and anti-festivals... Our ambition is to explore this field in which the concept is in action, it is performative, the way how 'philosophy' can be done as performance, opening and finding its own spaces ${ }^{11}$.

The performative philosophy sees, therefore, performance in the quality of thought and produces thought as performance, that is, philosophy as happening. Even when trying to escape from labels and definitions, the performative philosophy has been spread in the world, by means of publications, symposiums and conferences, in several and various versions $^{12}$. In 2014, for instance, within the project Philosophy-on-Stage from the University of Vienna, the performative philosopher Laura Cull, from the University of Surrey/England, joined the artist and performer Tess Denman Cleaver to conduct the Walking Lectures, based on the principle that one thinks more intensely the body when this is activated. In 2015, the philosophers Arno Böhler and Susanne Valerie Granzer developed the performance Nietzsche et cetera. Kant in Analyse, which places Kant under the shock of the reading of Nietzsche, being analyzed by Lou-Andreas Salome ${ }^{13}$.

For me, the performative philosophy is an unfolding resulting from my own project of a pop philosophy ${ }^{14}$, and since 2013 I have been trying, 
in theory and practice, to develop ways for its implementation in Brazil. Within this flow, I started to offer lectures and courses on the subject and, at the same time, to try forms of making philosophy that would increasingly involve my body, my imagination and my affection. One of the experiments was the opening table of the I International Symposium of Pop Philosophy, held in UNIRIO in May 2014. The subject of the table was Performance and Philosophy and was coordinated by me, with the presence of the French Professor Julie Amanty (Paris VIII) and the consecutive translation of Professor Tania Alice Feix (UNIRIO). What the audience did not know was that it was performance-lecture of the performer Tania Alice Feix, who created a fictional lecturer, Julie Amanty (the name already indicated the plot: Julie a menti = Julia lied), supposedly coming from the University of Paris VIII and guest of honor of the event. While the imaginary lecturer - staged by the actress and researcher Geneviève Lodovici - exhibited her theoretical-practice research on liminal corporeities with the face all hidden by bands, her intervention was being consecutively translated by Professor Tania Alice, the true author of the text and the $\operatorname{plot}^{15}$. The strong debates that followed were coordinated by me and were the most intense ones of the symposium. The opening table, on performance and philosophy, was not only about, but it was performative and philosophical itself ${ }^{16}$.

For the performative turn of the philosophy to be successful, it is necessary that it gives up the traditional yearning for being able to guide human beings in the search for the absolute and only truth e and the capacity to reach a form of universality with total and unrestricted comprehensiveness. The philosophical search for the most universal, mentioned in the beginning as one of the distinctive characteristics of the performative dimension of the philosophy, unfortunately carries in its core the trend for a certain lack of attention with the specific historical and cultural contexts of the investigated subjects. The extreme universalism of the western philosophy is evident, for instance, in the academic disinterest for the systems of thoughts of African, indigenous, eastern or even South American matrix. The recurrent - and inadmissible - argument says that if philosophy searches for the universal, it cannot be dealt with as a specific activity of a geopolitical region. Fortunately, the contemporary philosophy is learning to revise and to relativize its concept of universal, mainly from 
the fruitful dialogue with the field of arts in general, from which the idea of topologies of the being ${ }^{17}$ has been developed. Within this context, it can be claimed that the performative philosophy is always site-specific, anchored always and each time in the geographic, historical and cultural context of the bodies that practice it. It will be necessary, therefore, to ask what is done when philosophy is done in the contemporary Brazil.

The performing arts summon philosophy to have strength to support the paradoxes and the ambiguities of existence, but also to resist and to question the hegemonic ideologies. Precision should not be abandoned, but rather the extreme formality. It is necessary, for instance, to ask if the classroom, the linear text, the expositive lessons, the long lectures in congresses, they are still the most appropriate formats to make philosophy in the $21^{\text {st }}$ century. It will be essential to reactivate the bodies of the philosophers, perpetually sitting, either in chairs at their desks or at the academy chairs. Why not include corporal training techniques coming from the performing arts, as highly recommendable requirement in the training of future philosophy teachers?

Finally, it will be necessary to review the very notion of action, restricted to the fields of ethics and politics. While in the field of aesthetics, artistic actions are mobilizations so that art can happen, in the field of philosophy, philosophical actions are mobilizations so that the thought itself can happen, either by means of the engagement of the bodies, sexes, new technologies, daily situations, contents deriving from the mass culture, and, mainly, from the political challenges of our times. What is the l'avenir of these philosophical actions? This question will only be answered, in theory and practice, by the continuous occupation of the borders between performing arts and philosophy.

Grajaú, Rio de Janeiro, Spring of 2019.

\section{Notes}

1 The present essay is a revised and modified version of an oral communication presented in the Projeto Observatório Filosófico [Philosophical Observatory Project], carried through at Caixa Cultural do Rio de Janeiro on June 10, 2016 in a table shared with Professor PhD Marcia Tiburi. 
2 It is important to highlight that I consider here the use of the word deconstruction not only in the post-structuralist context but defining it as the mode of operation of the philosophers, from their beginning to the current days. My hypothesis is that even when not addressed explicitly, the characteristic thinking of philosophy always involves some deconstruction of the real, as something supposedly given, every time it makes its questions.

3 I am not referring here to the ontology only as a branch of philosophy. On the contrary, I am claiming, in line with Heidegger, that the whole philosophy, wanting it or not, is ontology. There are traditional ontologies that understand the being in a fixed and unchangeable way; post-metaphysical, the ones that understand the being as plural differences; and, finally, the negative ones, those that simply deny any possibility of understanding the being.

4 The $20^{\text {th }}$ century philosophies, especially by means of Heidegger's and Wittgenstein's works, have the language as central subject. But my work hypothesis concerning the terminological care of the philosophical gesture refers to the history of philosophy as a whole.

5 For a deeper reflection regarding the cross-border dimension of the skin, see the phenomenological essay of the French philosopher Jean-Luc Nancy (2014), intitled Essential Skin.

6 See the article of the French philosopher Jacques Derrida (1991) Signature, Event, Context of 1990, for a deeper reading of the precariousness of the distinction between constative and performative.

7 This is the thought-provoking thesis of the famous expert on the work of the sophists, the French Professor Barbara Cassin (2005), in her book The Sophistic Effect (1995).

8 See Hans-Thies Lehmann (2007), Post-Dramatic Theater (1999) and Josette Feral (2015), Além dos Limites - Teoria e Prática do Teatro (2011).

9 The written version of the debate is available in Revista ouvirOUver online (Ferracini; Feitosa, 2017).

10 In contemporary Greek, kairós is associated with the meteorological conditions of each region. In the Christian theology, kairós experienced an appropriation and was reinterpreted, especially in St Paul's epistles, as the time of the divine actions. In the old philosophy, the notion of kairós traces back to the issues of classic rhetoric, to the capacity of a speaker to adapt to the contingencies of a circumstance. In this case, the wisdom of corresponding to each occasion is a basic 
factor for the establishment of the kairological time. For the relation between kairós and rhetoric, see the book organized by Phillip Sipiora and James Baumlin (2002): Rhetoric and Kairos - Essays in History, Theory and Praxis (2002).

11 Transcription of the round table Qu'est-ce que la philo-performance?, held in Paris on June 28, 2014, during the international colloquium Théatre, performance, philosophie: croisements et transferts dans la pensée anglo-américaine. Available at: <http://labo-laps.com/quest-ce-philo-performance/>. Accessed on: 20 February 2018.

${ }^{12}$ It is noteworthy the Viennese project Philosophy-on-Stage (https:/www.univie.ac.at/performanz) and the international network of performative philosophy (https://www.performancephilosophy.ning.com), in which bibliographies and events related to the subject can be found. Since 2015 there is also a scientific magazine specialized in performative philosophy: <https://www.performancephilosophy.org/journal/pages/view/about>. Presently there are several groups working in Asia, Oceania and Latin America. In Brazil, I had the chance, with Professors PhD Tania Alice and Angela Donini, both from UNIRIO, to organize several courses, round tables and symposiums on the practical and theoretical relations between performance and philosophy within the research project filosofia pop: <http://dgp.cnpq.br/dgp/espelhogrupo/ $2330294403542324>$.

13 Transcriptions of these actions are available at: <http://homepage.univie. ac.at/arno.boehler/php/wp-content/The_Sea_Lies_Open_Cull_DenmanCleaver_Walks_extended-description.pdf> and: <http://homepage.univie.ac. at/arno.boehler/php/wp-content/Boehler_Granzer_Nietzsche_et_cetera_Tran skript.pdf>. Accessed on: 20 February 2018.

${ }^{14}$ On the idea of pop philosophy in Brazil, see my paper from 2001, O Que é Isto - Filosofia Pop? [What is this - Pop Philosophy?], as well as the critical study of Marcia Tiburi in 2016 intitled A Filosofia e seus conteudos desprezados: Filosofia Pop em Questão [Philosophy and its Despised Contents: Pop Philosophy in Question].

15 The full text of the lecture Corporeidades Liminares was published in the magazine Percevejo online (Feix, 2014).

16 Another philoperformative action that I had a chance to carry through was the project Piloto para um trem transcultural [Pilot for a transcultural train], whose intention was to transform the time spent into urban mobility, an alienated time, in fertile and creative time. Together with Professor Cecilia Dinardi 
(City University of London), I coordinated the accomplishment of several performances and creative workshops in a train wagon of the Central station of Rio de Janeiro during 5 days in April 2016. The activities were filmed to be shown in an interactive installation - including a mockup of the train - in the Festival Multiplicidade (May 16, 2016). The result is available in video on the Internet: <https://vimeo.com/166043561>. Accessed on: 1 February 2018.

17 More on the subject can be read in the article of the Puerto Rican philosopher, Professor of Brown University, Nelson Maldonado-Torres (2008), intitled $A$ Topologia do Ser e a Geopolitica do Conhecimento. Modernidade, Império e Colonialidade [The Topology of the Being and the Geopolitics of the Knowledge. Modernity, Empire and Coloniality (2003).

\section{References}

AUSTIN John Langshaw. How to do Things with Words. New York: Oxford University Press, 1975.

BUTLER, Judith. Performative Acts and Gender Constitutution: An Essay in Phenomenology and Feminist Theory. Theatre Journal, Baltimore, v. 40, n. 4, p. 519-531, 1988. Available at: <https:/www.amherst.edu/system/ files/media/1650/butler_performative_acts.pdf>. Accessed on: 28 February 2018.

CASSIN, Barbara. O Efeito Sofístico. São Paulo: Ed. 34, 2005.

COHEN, Renato. Performance como Linguagem. São Paulo: Perspectiva, 2002.

DEBRAY, Régis. Eloge des Frontières. Paris: Gallimard, 2010.

DELEUZE, Gilles. Différence et Répétition. Paris: Puf, 1968.

DERRIDA, Jacques. Assinatura, Acontecimento, Contexto. In: DERRIDA, Jacques. Margens da Filosofia. São Paulo: Papirus, 1991. P. 349-373.

DERRIDA: The Movie. Direção: Kirby Dick e Amy Ziering Kofman. França e EUA: 85 mins, 2002.

DESCARTES, René. Les Passion de l'âme. In: DESCARTES, René. Descartes, Oeuvres, Lettres. Paris: Gallimard, 1953.

FEITOSA, Charles. O que é isto: filosofia pop?. In: LINS, Daniel (Org.). Nietzsche e Deleuze. Rio de Janeiro: Relume Dumará, 2001. P. 95-104.

FEIX, Tania Alice. Corporeidades Liminares. O Percevejo online, Rio de Janeiro, v. 6, n. 1, p. 234-249, jan./jun. 2014. 
FÉRAL, Josette. Além dos Limites - Teoria e Prática do Teatro. São Paulo: Perspectiva, 2015.

FERRACINI, Renato; FEITOSA, Charles. A Questão da Presença na Filosofia e nas Artes Cênicas. Revista ouviuOUver, Uberlândia, v. 13, n. 1, p. 106-119, 2017. Available at: <http://www.seer.ufu.br/index.php/ouvirouver/ article/view/37043>. Accessed on: 10 February 2018.

LEHMANN, Hans-Thies. Teatro Pós-Dramático. São Paulo: Cosac Naify, 2007.

MALDONADO-TORRES, Nelson. A Topologia do Ser e a Geopolítica do Conhecimento. Modernidade, Império e Colonialidade. Revista Crítica de Ciências Sociais, Coimbra, n. 80, p. 71-114, mar. 2008.

MEDEIROS, Maria Beatriz de. Consideraciones sobre el arte del performance, Respuesta a Avelina Lesper, Ursula Ochoa y Carlos Monroy. Esferapublica, 2010. Available at: <http://esferapublica.org/nfblog/consideraciones-sobre-el-artedel-performance/>. Accessed on: 20 February 2018.

NANCY, Jean Luc. Pele Essencial. O Percevejo online, Rio de Janeiro, v. 6, n. 1, p. 1-12, jan./jun. 2014. Available at: <http://www.seer.unirio.br/index.php/ opercevejoonline/article/view/5067/4506>. Accessed on: 10 February 2018.

NIETZSCHE, Friedrich. Die Geburt der Tragödie. Berlin; New York: DTV, KSA I, 1988a.

NIETZSCHE, Friedrich. Nachgelassene Fragmente 1884-1885. Berlin; New York: DTV, KSA XI, 1988b.

PRECIADO, Paul Beatriz. Texto Yonqui. Madrid: Espasa Calpe, 2008.

SANTOS, César Ricardo Simoni. Sobre limites e fronteiras: a reprodutibilidade do estoque territorial para os fins da acumulação capitalista. Revista Confins [Online], v. 12, p. 1-12, 2011. Available at: <http://journals.openedition. org/confins/7081>. Accessed on: 8 February 2018.

SCHECHNER, Richard. Between Theater and Anthropology. Philadelphia: UPP, 1985.

SCHECHNER, Richard. O que é performance?. O Percevejo online, Rio de Janeiro, n. 12, ano 11, p. 25-50, 2003.

SIPIORA, Phillip; BAUMLIN, James S. (Org.). Rhetoric and Kairos - Essays in History, Theory and Praxis. New York: SUNY Press, 2002. 
TIBURI, Marcia. A Filosofia e seus conteúdos desprezados: Filosofia Pop em Questáo.

Revista Sinais Sociais, Rio de Janeiro, v. 10, n. 30, p. 95-124, jan./abr. 2016.

TURNER, Victor. The Anthropology of Performance. New York: Paj Publications, 1988.

TURNER, Victor. From Ritual to Theatre. New York: Paj Publications, 1992.

UCHOA, Ursula. La incesante repetición del gesto (los 10 gestos y elementos formales más utilizados en el arte de acción). Esferapublica, 2008. Available at: $<$ http://esferapublica.org/nfblog/la-incesante-repeticion-del-gesto-los-10-gestos-yelementos-formales-mas-utilizados-en-el-arte-de-accion/>. Accessed on: 20 February 2018.

Charles Feitosa is a Full Professor and researcher of the Graduate Program in Performing Arts of Universidade Federal do Estado do Rio de Janeiro (PPGAC/UNIRIO) and of Philosophy in Universidade Federal do Rio de Janeiro (PPGF-UFRJ). Coordinator of Pop-Lab (Laboratory of Studies in Pop Philosophy).

ORCID: http://orcid.org/0000-0003-2554-3901

Email:philo_bureau@hotmail.com

This original paper, translated by Ananyr Porto Fajardo, is also published in Portuguese in this issue of the journal.

Received on April 30, 2019

Accepted on October 21, 2019

Editor-in-charge: Patrick Campbell Editor-in-charge: Laura Cull Ó Maoilearca Editor-in-charge: Luciana da Costa Dias

This is an open-access article distributed under the terms of the Creative Commons Attribution License 4.0 International. Available at: <http://creative commons.org/licenses/by/4.0>. 